\title{
A COMPARISON OF THE EFFECTS OF HALOTHANE AND OTHER ANAESTHETIC AGENTS ON HEPATO-CELLULAR FUNCTION IN PATIENTS SUBMITTED TO ELECTIVE OPERATIONS
}

\author{
B. KaLow, E. Rogoman, aNd F.H. Sims"
}

\section{INTRODUCTION}

THE CONTROVERSY over the hepato-toxic effects of the halogenated anaesthetic agents, particularly halothane, is still not resolved despite many years of continued study. The present position has been summarized in a number of recent reviews. ${ }^{1-6}$

A low incidence of serious liver damage following halothane was established by the U.S. National Halothane Study ${ }^{7}$ and has been supported by similar findings reported to the British Committee on the Safety of Medicines. ${ }^{8}$ Incidents of serious hepatic damage following halothane continue to be reported however, ${ }^{8-11}$ and it has been suggested that such complications occur more frequently in patients having multiple exposures to the agent. ${ }^{12,13}$ This suggestion is, however, disputed by some. ${ }^{2,14}$

Evidence directly relating halothane exposure to liver damage in a cause and effect relationship continues to be unconvincing because of the high selectivity of the cases reported and the impossibility of excluding other causes of the hepatocellular damage.

The purpose of the study described in this paper, was to examine the preoperative and post-operative hepatic function of a group of patients submitted to elective operations and to compare the incidence and magnitude of the enzyme changes in patients given halothane or methoxyflurane to those occurring in patients anaesthetized with nitrous oxide and analgesic supplements.

Estimations were made of the activities of seven enzymes in pre-operative and post-operative blood samples, including a very sensitive test of hepato-cellular alteration, Arginino-Succinate Lyase (ASAL). Such enzyme tests have been shown to be capable of detecting sub-clinical hepatic involvement which is known to occur with greater frequency following cholecystectomy. ${ }^{15}$

If appreciable differences in toxicity of the various anaesthetic agents occurred in normal individuals, as distinct from the rare patients with possible hypersensitivity, it could be expected that such differences might appear in the incidence and magnitude of elevated serum enzyme activity in post-operative blood samples. Although such differences may escape detection in the types of surgical procedure which are associated with only a low incidence of hepato-cellular alteration, the group of patients who had cholecystectomy might be expected to provide a particularly sensitive index of hepatic involvement. In our series, no significant differences were found between the several anaesthetic groups, either in the

\footnotetext{
'Departments of Anaesthesia and Clinical Biochemistry, Women's College Hospital and University of Toronto, Toronto, Canada M5S $1 \mathrm{~B} 2$.
}

Canad. Anaesth. Soc. J., vol. 23, no. 1, January 1976 
incidence of detectable hepatic alteration of function, or in the magnitude of the rise of enzyme activity, when this occurred in the post-operative blood samples.

\section{Patients and Methods}

The patients studied were a group of approximately 500 who were admitted to Women's College Hospital for elective operations over a period of ten months. They were predominantly female ( 96 per cent) ranging in age from 15 to 90 , with a mean of 46 years. Some were excluded from the statistics due to the presence of significant disease other than the surgical condition for which they were admitted. Others who showed elevated enzyme activity in the pre-operative sample were also excluded. This left a total of $\mathbf{4 7 8}$ patients, all of whom remained in hospital at least five days post-operatively.

Seven enzyme determinations were performed on the serum of each of these patients. Blood samples were withdrawn pre-operatively for base-line assay, then on days three and five post-operatively. If there was continued elevation of the enzyme levels, further samples were taken, when possible, at two-day intervals until return of the results to normal, or until the patient was discharged.

Premedication for operation was usually with meperidine or pantopon, and induction was with thiopentone, followed by nitrous oxide and oxygen.

Maintenance of anaesthesia in one group was with nitrous oxide, oxygen, and analgesic supplement (meperidine, Innovar, or pantopon). A second group had nitrous oxide and oxygen supplemented with halothane, while a third group had nitrous oxide, oxygen, and methoxyflurane. The choice of anaesthetic agent used in any particular case was left to the judgment of the anaesthetist who was aware that the post-operative condition of the patient was being studied. Where indicated, muscle relaxation was obtained with succinyl dicholine, d-tubocurarine or a combination of both.

A relatively small number of patients were given halothane for cholecystectomy. The reason for this was the general controversy over the possible hepato-cellular toxicity of halothane, and a circular letter issued by the Coroner's office advising rejection of halothane for operations involving the liver. Halothane was also rejected as an anaesthetic agent in 20 of the patients who gave a history of previous hepatitis.

The enzyme activities measured in the serum samples removed were ArgininoSuccinate lyase (ASAL), Alanine aminotransferase (ALT), Aspartate aminotransferase (AST), Isocitrate dehydrogenase (ICD), Alkaline Phosphatase (AP), Lactate dehydrogenase (LD), Creatine Kinase (CK). The methods used were standard techniques as described by Campanini, et al. for ASAL, ${ }^{16}$ by Henry, et al. for ALT and AST, ${ }^{17}$ Bowers for ICD, ${ }^{18}$ Amador, et al. for $\mathrm{LD},{ }^{19}$ Babson for $\mathrm{AP},{ }^{20}$ and Rosalki for CK. ${ }^{21}$

Normal ranges for these enzymes were established by a statistical analysis of the pre-operative levels. The upper limit of normal was taken as the mean plus three standard deviations for the enzymes ALT, AST, ICD, AP, LD, and CK, which show an approximately normal distribution. The distribution of ASAL is skewed, and an upper limit of 4 was taken, since this included 97 per cent of the pre-operative 
values. This figure is in agreement with that taken by Campanini et al., ${ }^{16}$ as the upper limit of the normal range.

The comparative sensitivity and specificity of these enzymes was discussed in a previous publication.22 ASAL was the most sensitive index of hepato-cellular damage and was approximately twice as sensitive as ALT.

\section{RESUlts}

Of the total group of approximately 500 patients studied, 80 showed normal enzyme levels in the pre-operative sample, but significant elevations in the postoperative samples.

Table I gives an analysis of the incidence of these elevated levels, with the different types of anaesthetic agent.

It is seen that $40-50$ per cent of patients submitted to cholecystectomy showed detectable hepato-cellular alterations in the post-operative period. Other types of operation were associated with a much lower incidence of enzyme changes. In columns 5 and 8 of Table I the standard error is given of the difference between the incidence of abnormal tests for halothane and methoxyflurane as compared with the incidence of abnormal tests following nitrous oxide, oxygen, and analgesic supplement. With the possible exception of methoxyflurane in the pelvic operation group, there are no significant differences between the nitrous oxide-oxygenanalgesic group and those given halothane or methoxyflurane.

In order to determine whether the magnitude of the enzyme elevations were significantly different in the three anaesthetic groups, the degree of the postoperative enzyme increase was expressed as a multiple of the upper limit of the normal range, and the average values of these maximum levels are detailed in Table II.

It is seen that there is no significant difference between the anaesthetic groups in the magnitude of the average enzyme elevations in the post-operative period.

The changes in serum ASAL activity for the cholecystectomy patients with elevated enzyme levels in the post-operative period are illustrated in Figure 1. There are no significant differences between the different anaesthetic groups in the time taken to reach the maximum enzyme activity, or in the general shape of the curve. In this group of cholecystectomy patients the post-operative temperature elevations, the initial leucocyte counts, and the possible effect of the performance of a cholangiogram during the operation were also examined.

It was found that the average temperature elevation and the time relationship of the temperature elevations were the same in the three anaesthetic groups. There was no correlation between the initial leucocyte count and the elevation of temperature or of enzyme activity in the post-operative period. The enzyme elevations observed were not significantly different in the group having operative cholangiograms from those having no cholangiogram.

\section{Discussion}

The occurrence of detectable post-operative hepato-cellular alterations in an 


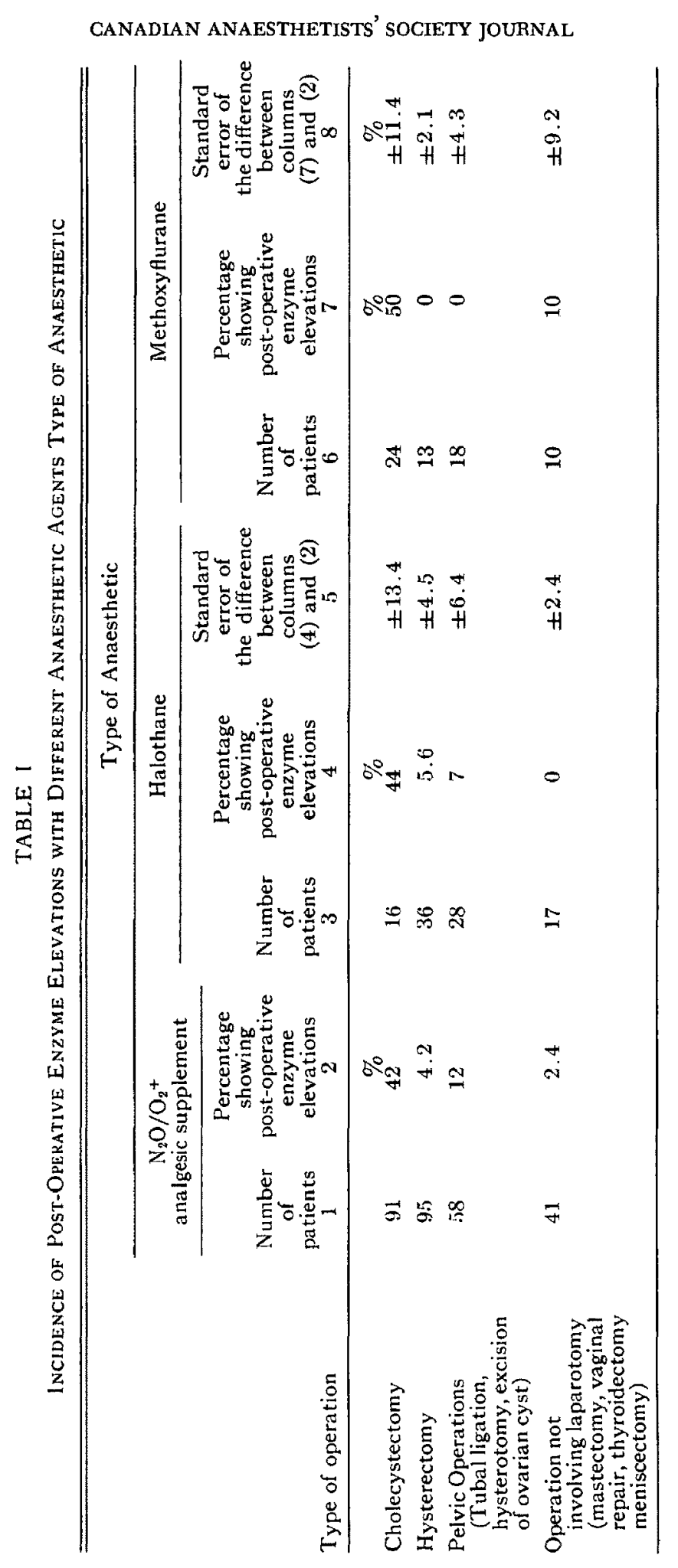




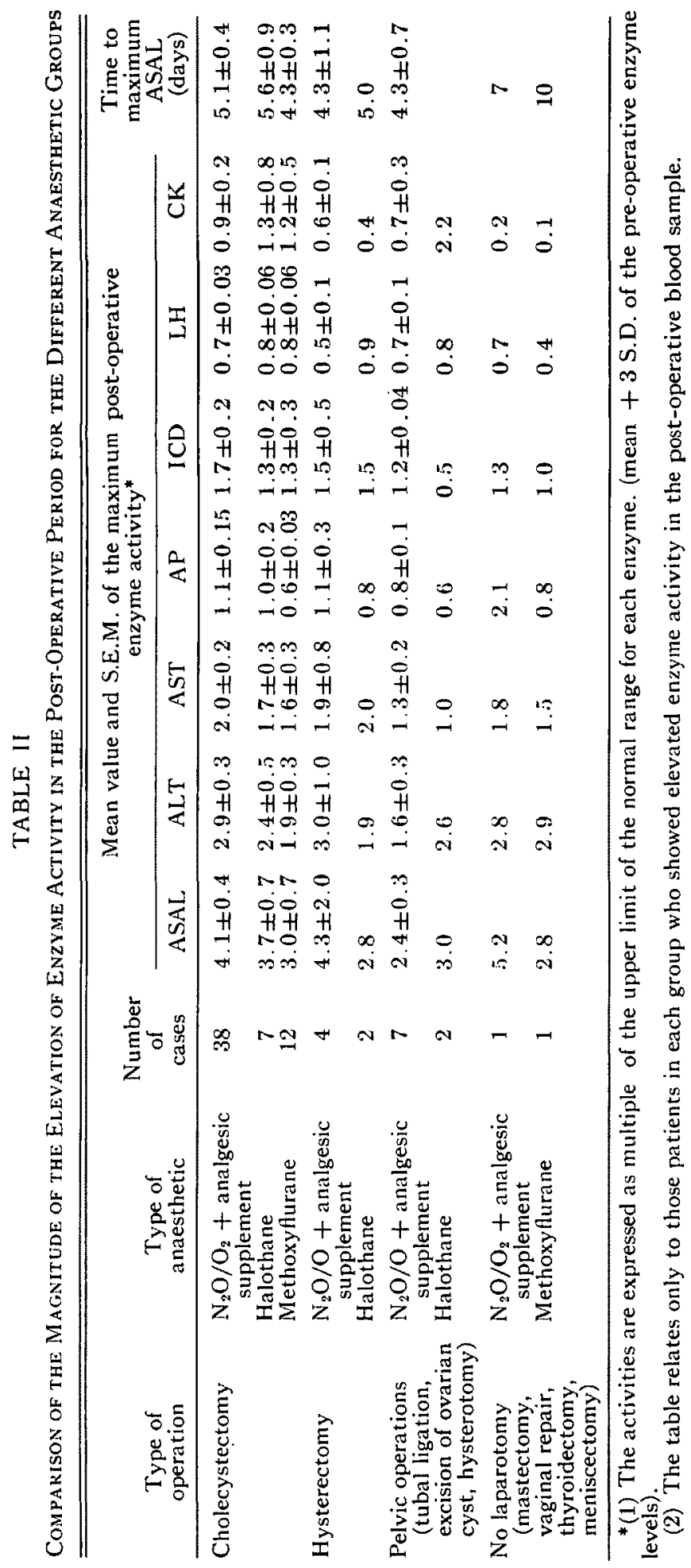


ENZYME

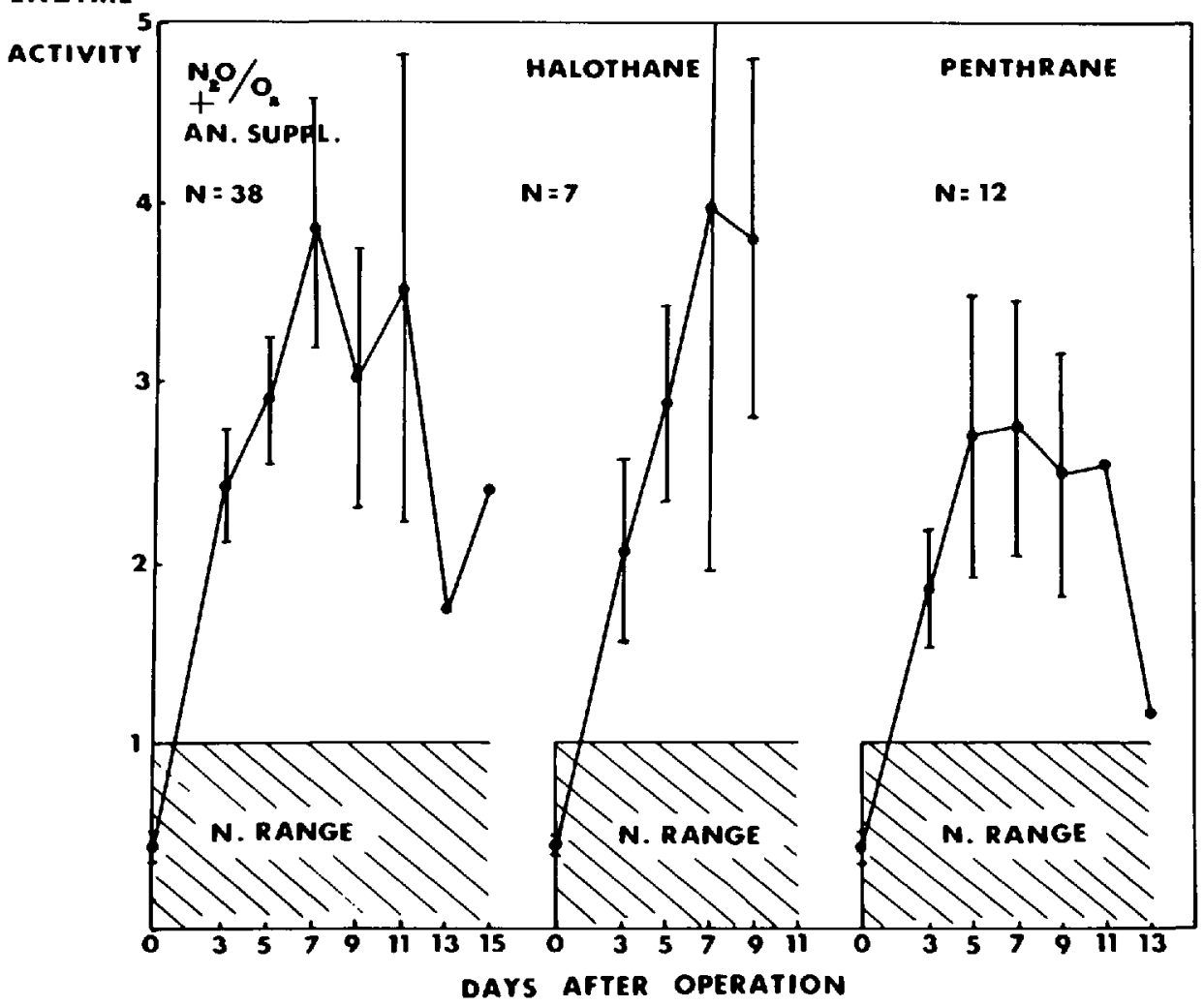

FigurE 1. Mean values of ASAL activities for pre-operative and post-operative serum samples from patients showing an elevation of enzyme activity in the post-operative period. The results for each anaesthetic group are plotted separately, and for each value the standard error of the mean is indicated.

appreciable number of patients has been well established. The substantially higher proportion of patients submitted to cholecystectomy who show these changes is also well known. ${ }^{23,15}$ The cause of these hepatic changes is not clear. They are probably due to hypoxia of liver cells caused by interference with blood flow. This could arise in the cholecystectomy patients from traction at the time of operation, with secondary hepatocellular oedema. There is evidence that it may be aggravated in this group of patients by biliary diskinaesia and raised pressure post-operatively in the biliary system. ${ }^{24}$ This might cause a further reduction in the portal blood flow. Such minimal hepatic changes are reversible, and in our cases were clinically undetectable. They did not lead to clinical jaundice and the serum conjugated bilirubin concentration in a selected group of patients was no greater than $0.4 \mathrm{mg} \%$.

It would seem, therefore, that the liver of the post-operative patient is likely to contain many cells suffering from marginal hypoxia, particularly following cholecystectomy. Such cells might be expected to be specially sensitive to anaesthetic toxicity, or toxicity from any drug. The fact that there was no demonstrable difference in our series between any of the types of anaesthetic is evidence that there was no significant hepato-toxic effect of halothane in the patients studied. 
Since the other drugs used were common to all the patients submitted to operation, these should not have interfered with the comparison of anaesthetic agents. The series is too small to hope to detect the rare patient with hypersensitivity. However, the series confirms that significant subclinical hepatic alterations do occur in a considerable number of post-operative patients regardless of the type of anaesthetic. It is likely that from time to time more severe damage in individual patients may lead to clinically apparent jaundice, and it would be scientifically unjustifiable to attribute this without other proof to the anaesthetic agent simply because it occurs in a specified time relationship to the operation.

A prospective study to examine the post-operative course of a much larger group of patients, comparing different anaesthetic agents and techniques would seem urgently necessary. This could be done by the examination of pre-operative and post-operative ALT levels (a test readily available, which is nearly as sensitive as ASAL) in a much larger series of cholecystectomy patients.

Only through such a large prospective study with adequate controls and documentation can it be proven whether halothane is, or is not, safer than the nonhalogenated anaesthetic agents in general use.

\section{SUMMARY}

In an attempt to gather objective evidence of possible hepato-cellular toxicity of the halogenated anaesthetics halothane and methoxyflurane pre-operative and post-operative enzyme estimations were done on patients admitted for elective operations. The series of approximately 500 cases included 160 patients submitted to cholecystectomy, an operation associated with a high percentage of detectable alteration of hepatocellular function in the post-operative period. There was no significant difference between the groups of patients receiving halothane, methoxyflurane, or nitrous oxide and oxygen with analgesic supplement. The magnitude of the increased post-operative enzyme activity and the post-operative temperature elevation were not significantly different in the three groups studied.

\section{RÉSUMÉ}

Les taux d'enzymes ont été mesurés pendant la période pré per-opératoire chez 500 patients admis à l'hôpital pour une chirurgie élective. Cette série comprend 160 patients ayant subi une cholécystectomie, intervention où l'on retrouve un pourcentage élevé d'altérations décelables de la fonction hépato-cellulaire dans la période post-opératoire. Les patients furent divisés en trois groupes: le premier ayant reçu de l'halothane, le deuxième du penthrane et le troisième du protoxyde d'azote avec un narcotique intraveineux. On a supposé que la différence de toxicité hépato-cellulaire des différents agents anesthésiques se réflètait par une différence significative de l'élévation des enzymes post-opératoires, en particulier chez les malades cholécystectomisés.

Il n'a pas été trouvé de différences significatives du taux des enzymes sériques étudiés chez les malades des trois groupes et ceci même chez ceux qui ont subi un cholécystectomie. 
Donc cette étude n'a pas fait la preuve objective de l'hépato-toxicité des anesthésiques halogénés, halothane et méthoxyflurane, chez des patients qui ne montrent pas d'hypersensibilité à ces agents.

\section{ACKNOWLEDGMENTS}

The authors wish to thank the staff surgeons of the hospital for their willing co-operation in this study, the Dorothy Graham Research Fellowship for financial support, and Miss Paula Rautanon for valuable technical help.

\section{REFERENCES}

1. DaviEs, G.E. Is halothane hepatotoxicity an allergic reaction to halothane? Proc. R. Soc. Med. 66: 55 (1973).

2. Dykes, M.H.M., Gilbert, J.P., \& McPeeK, B. Halothane in the United States. An appraisal of the literature on "halothane hepatitis" and the American reaction to it. Br. J. Anaesth. 44: 925 (1972).

3. GotTlieb, L.S. \& TREY, C. The effects of fluorinated anaesthetics on the liver and kidneys. Annu. Rev. Med, 25: 411 (1974).

4. McPeek, B., Mathiev, A., \& Guralnick, W.C. Fact or fancy - a reasoned view of halothane. J. Oral Surg. 32: 8 (1974).

5. SHERLOCK, S. Halothane hepatitis. Gut, 12: 324 (1971).

6. Simpson, B.R., Strunin, L., \& Walton, B. Halothane hepatitis - fact or fallacy? Proc. R. Soc. Med. 66: 56 (1973).

7. Bunker, J.P., Forrest, W.H., Mosteller, F., \& VandaM, L.D. The National Halothane Study, Washington, U.S. Government Printing Office (1966).

8. InMan, W.H. \& Mushin, W.W. Jaundice after repeated exposure to halothane: an analysis of Reports to the Committee on Safety of Medicines. Br. Med. J. 1: 5 (1974).

9. Mushin, W.W., Rosen, M., \& Jones, E.V. Post-halothane jaundice in relation to previous administration of halothane. Br. Med. J. 3: 18 (1971).

10. They, C., Lipworth, L., Chalmers, T.C., Davimson, C.S., Gottlieb, L.S., Popper, H., \& SAUNDERs, S.J. Fulminant hepatic failure. Presumable contribution of halothane. New Eng. J. Med., 279: 798 (1968).

11. Dykes, M.H.M. Unexplained post-operative fever. Its value as a sign of halothane sensitization. J.A.M.A. 216: 641 (1971).

12. Huches, M. \& Powell, L.W. Recurrent hepatitis in patients receiving multiple halothane anaesthetics for radium treatment of the cervix uteri. Gastroenterology 58: $790(1970)$.

13. Davis, P. \& Holdsworth, C.D. Jaundice after multiple halothane anaesthetics administered during the treatment of carcinoma of the uterus. Gut, 14: 566 (1973).

14. McPeEK, B. \& GLBERT, J.P. Onset of post-operative jaundice related to anaesthetic history. Br. Med. J. 3: 615 (1974).

15. Hobson, R.W., Conant, C., Fleming, A., Mahoney, W.D., \& Baugh, J.H. Post-operative serum enzyme patterns. Milit. Med. 136: 624 (1971).

16. Campanini, R.Z., Tapia, R.A., Sarnat, W., \& Natelson, S. Evaluation of serum argininosuccinate lyase (ASAL) concentrations as an index to parenchymal liver disease. Clin. Chem. 16: 44 (1970).

17. Henry, R.J., Chiamori, J.N., Golub, O.J., \& Berkman, S. Revised spectrophotometric methods for the determination of glutamic-oxalacetic transaminase glutamic-pyruvic transaminase, and lactic dehydrogenase. Am. J. Clin. Path. 34: 381 (1960).

18. BowErs, G.N., Jr. Measurement of isocitric dehydrogenase activity in body fluids. Clin. Chem. 5: 509 (1959).

19. Amador, E., Dorfman, L.E., \& Wacker, W.E.C. Serum lactic dehydrogenase activity: an analytical assessment of current assays. Clin. Chem. 9: 391 (1963).

20. BABson, A.L. Phenolphthalein monophosphate, a new substrate for alkaline phosphatase. Clin. Chem. 11: 789 ( 1965).

21. Rosalkr, S.B. An improved procedure for serum creatine phosphokinase determination. J. Lab. Clin. Med, 69: 696 (1967). 
22. Sms, F.H. \& Rautanon, P. Serum Arginino-Succinate lyase: observations on the sensitivity and specificity of this test in the detection of minimal hepato-cellular damage. Clinical Biochemistry 8: 213-221 (1975).

23. Aymes, P.R. \& Williard, T.B. Serum glutamic oxalacetic transaminase levels in 266 surgical patients. Ann. Int. Med. 52: 1279 (1960).

24. HolTzER, J.D. \& Hulst, S.G. Confirmation of post cholecystectomy biliary dyskinesia by elevation of serum transaminases (GOT and GPT) after injection of morphine? Acta Med. Scand, 194: 221 (1973). 